Available online on 15.06.2020 at http://jddtonline.info
Open Access to Pharmaceutical and Medical Research
unrestricted non-commercial use, provided the original work is properly cited

Open 1 Access

Review Article

\title{
Majoon-E-Piyaz: A Potent Unani Formulation for Premature Ejaculation
}

\author{
Alam Shah*, Anjum Nighat, Akhtar Jamal, Bashir Fouzia, Khan Asim Ali \\ Central Council for Research in Unani Medicine, Ministry of AYUSH, Govt. of India, 61-65 Institutional Area, D-Block, Janakpuri, New Delhi- \\ 110058
}

\begin{abstract}
Sur'at-e-Inzāl (Premature Ejaculation) is the most prevalent male sexual dysfunction affecting 25 - $40 \%$ global population of men. It is a universal disorder and is independent of age, social or marital status. It has a significant impact on both- patients and their partners, causing distress, anxiety and relationship difficulties affecting the quality of life. Several aetiologies have been proposed by various researchers which are not evidence-based but speculative. Accordingly the International Society for Sexual Medicine (ISSM) issued treatment guidelines for Premature Ejaculation (PE) recommending Serotonergic Antidepressants (SSRIs) and Local Anaesthetics (LA) for its management in modern medicine. However, these treatments were not actually developed for PE, and have limitations associated with their off-label use. Furthermore, nearly all the recommended drugs have a wider spectrum of adverse effects and serious drug interactions which sometimes could be fatal. On the other hand, centuries old Unani medicine offers a complete line of treatment for Sur'at-e-Inzāl based on traditional knowledge and experience. Unani physicians devised a large number of poly-herbal recipes which are still in vogue. Majoon-e-Piyaz (MP) is one of the compound Unani formulations which are in use for the treatment of premature ejaculation since centuries. This article is an attempt to summarize scientific investigations in support of the claim made by Unani physicians regarding Majoon-e-Piyaz (MP).
\end{abstract}

Keywords: Sur'at-e-Inzāl, Premature Ejaculation, Majoon-e-Piyaz, Unani Medicine

Article Info: Received 22 March 2020; Review Completed 14 May 2020; Accepted 20 May 2020; Available online 15 June 2020

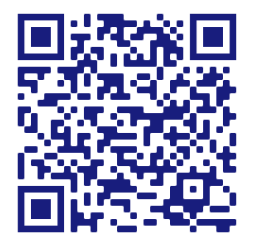

Cite this article as:

Alam S, Anjum N, Akhtar J, Bashir F, Khan AA, Majoon-E-Piyaz: A Potent Unani Formulation for Premature Ejaculation, Journal of Drug Delivery and Therapeutics. 2020; 10(3-s):330-334 http://dx.doi.org/10.22270/jddt.v10i3-s.4123

\section{*Address for Correspondence:}

Block, Janakpuri, New Delhi-110058

\section{Introduction}

Unani System of Medicine is an ancient system dates back to the times of its origin when Greek physician Hippocrates (370-460 BC) freed Medicine from magic and superstitions and gave it the status of science. In Unani medicine, four types of treatment are employed which include Regimenal therapy (Ilaj Bil Tadbir), Dietotherapy (Ilaj Bil Ghiza), Pharmacotherapy (Ilaj Bil Dawa) and Surgery (Ilaj-Bil Yad). Pharmacotherapy deals with the use of naturally occurring drugs, mostly herbal, though drugs of animal and mineral origin are also used. Since in this system stress is laid on the particular temperament of the individual, the drugs are prescribed according to the temperament of the patient, thus accelerating the process of recovery and also eliminating the risk of drug reaction. Unani physicians encouraged poly-pharmacy and devised a large number of poly-pharmaceutical recipes which are still in vogue. In Unani medicine, although general preference is for single drugs, compound formulations are also employed in the treatment of various diseases. Majoon-e-Piyaz (MP) is one of the compound Unani formulations which are in use for the treatment of premature ejaculation since centuries. Although Unani medicine describes holistic approach for the treatment of numerous disease and disorders related to every bodily system but its role in dealing with male sexual disorders is invincible establishing Unani physicians' reputation in the field.

\section{Description}

Majoon-e-Piyaz is a dark brown semi solid preparation with characteristic odour and sweet taste which is being prescribed with great reputation from centuries for the treatment of Sur'at-e-Inzāl i.e. Premature Ejaculation. According to different Unani Pharmacopoeias this compound formulation is exclusively used as Muqawwi-eBah (aphrodisiac) and Mumsik (semen retentive) for the treatment of male sexual disorders - Sur'at-e-Inzāl (premature ejaculation), Zof-e-Bah (sexual debility) and Jiryan (spermatorrhoea) [1,2]. 
Table 1: Composition of Majoon-e-Piyaz [1,2]

\begin{tabular}{|l|l|l|l|l|}
\hline S.N. & Ingredients & Botanical names & Part used & Quantity \\
\hline 1. & Tudri surkh & Cheiranthus cheiri L. & Seed & $35 \mathrm{~g}$ \\
\hline 2. & Tudri safaid & Matthiola incana R.Br. & Seed & $35 \mathrm{~g}$ \\
\hline 3. & Salab Misri & Orchis latifolia L. & Tuber & $35 \mathrm{~g}$ \\
\hline 4. & Behman Surkh & Salvia haematodes . & Root & $35 \mathrm{~g}$ \\
\hline 5. & Behman Safaid & Centaurea behen L. & Root & $35 \mathrm{~g}$ \\
\hline 6. & Zanjabeel & Zingiber officinale Rosc. & Rhizome & $35 \mathrm{~g}$ \\
\hline 7. & Tukhm-e-Piyaz & Allium cepa L. & Seed & $35 \mathrm{~g}$ \\
\hline 8. & Tukhm-e-Turb & Raphanus sativus L. & Seed & $35 \mathrm{~g}$ \\
\hline 9. & Tukhm-e-Gandana & Allium ascalonicum L. & Seed & $35 \mathrm{~g}$ \\
\hline 10. & Tukhm-e-Shalgam & Brassica rapa L. & Seed & $35 \mathrm{~g}$ \\
\hline 11. & Talmakhana & Hygrophila auriculata Schum.)Heine. & Root & $35 \mathrm{~g}$ \\
\hline 12. & Musli safaid & Chlorophytum arundinaceum Baker. & Root & $35 \mathrm{~g}$ \\
\hline 13. & Musli siyah & Curculigo orchioides Gaertn. & Onion extract & $1.5 \mathrm{lit}$ \\
\hline 14. & Aab-e-Piyaz Safaid & Allium cepa L. & Crystals & $1.5 \mathrm{~kg}$ \\
\hline 15. & Qand Safaid & Sugar & & \\
\hline
\end{tabular}

\section{Method of preparation [2]}

a) Take all ingredients of Pharmacopoeial quality.

b) Clean, wash, dry and powder ingredients no. 1 to 13 separately.

c) Peel the ingredient no. 14, cut into small pieces and make paste. Squeeze the paste carefully in a muslin cloth to obtain the juice $(A a b)$.

d) Weigh each ingredient and mix together and keep separately.

e) Dissolve ingredient no. 15 with ingredient no. 14 on low heat and boil the content.

f) At the boiling stage add the $0.1 \%$ citric acid, mix thoroughly and heat the content till Qiwam of 75 Brix is obtained.

g) Remove vessel from flame, in hot condition add the mixed powder of the ingredient no. 1 to 13 followed by $0.1 \%$ of sodium benzoate and mix thoroughly to prepare the homogenous blend.

h) Allow it to cool at room temperature.

i) Store in containers and make them air tight to protect from light and moisture.

\section{Physicochemical Data of Majoon-e-Piyaz [3]}

\begin{tabular}{|l|l|}
\hline Appearance & Semi solid \\
\hline Colour & Dark brown \\
\hline Smell & Onion like \\
\hline Taste & Sweet tending bitter \\
\hline Alcohol soluble matter & $19.53-21.35 \%$ \\
\hline Water soluble matter & $32.40 \%$ \\
\hline
\end{tabular}

\begin{tabular}{|l|l|}
\hline \multicolumn{2}{|l|}{ Successive extractives } \\
\hline Pet. ether & $2.33-2.62 \%$ \\
\hline Chloroform & $0.49-0.50 \%$ \\
\hline Ethyl alcohol & $5.22-6.08 \%$ \\
\hline
\end{tabular}

\begin{tabular}{|l|l|}
\hline \multicolumn{2}{|l|}{ pH value } \\
\hline pH of $1 \%$ solution & 4.90 \\
\hline pH of $10 \%$ solution & 4.60 \\
\hline
\end{tabular}

\begin{tabular}{|l|l|}
\hline Bulk density & $1.34-1.35$ \\
\hline Total ash & $1.17-1.32 \%$ \\
\hline Water soluble ash & $0.36-0.41 \%$ \\
\hline Acid insoluble ash & $0.25 \%$ \\
\hline Volatile oil & Traces \\
\hline Saponification value & 152.79 \\
\hline Iodine value & $77.98-80.92$ \\
\hline Acid value & $27.14-30.28$ \\
\hline Alkaloids & $0.02 \%$ \\
\hline Total Phenolics & $0.24-0.52 \%$ \\
\hline Resin & $0.90-1.45 \%$ \\
\hline Reducing sugar & $13.24-13.31 \%$ \\
\hline Non-reducing sugar & $45.22-45.28 \%$ \\
\hline Crude fibre & $1.09-1.38 \%$ \\
\hline
\end{tabular}


Thin Layer Chromatography [3]

\begin{tabular}{|c|c|c|c|c|}
\hline Extract & Solvent system & Spray/Treatment & No. of spots & Rf. values \\
\hline Pet. ether & $\begin{array}{c}\text { Benzene, Ethyl acetate } \\
(2: 1)\end{array}$ & $5 \% \mathrm{H}_{2} \mathrm{SO}_{4}$ in ethanol & 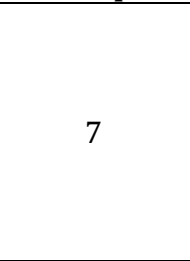 & $\begin{array}{l}0.86 \\
0.85 \\
0.76 \\
0.44 \\
0.41 \\
0.26 \\
0.17\end{array}$ \\
\hline- do- & Cyclohexane, Ethyl acetate (4:1) & Iodine vapour & 3 & $\begin{array}{l}0.88 \\
0.39 \\
0.31 \\
\end{array}$ \\
\hline Chloroform & $\begin{array}{c}\text { Ethanol, Chloroform, Butanol, } \\
\text { Ammonia Solution }(3: 3: 4: 1)\end{array}$ & Dragendroff's reagent & 4 & $\begin{array}{l}0.90 \\
0.68 \\
0.36 \\
0.11 \\
\end{array}$ \\
\hline Chloroform & Cyclohexane, Ethyl acetate (4:1) & Iodine vapour & 2 & $\begin{array}{l}0.82 \\
0.70 \\
\end{array}$ \\
\hline Ethanol & -do- & - do- & 3 & $\begin{array}{l}0.78 \\
0.33 \\
0.27 \\
\end{array}$ \\
\hline
\end{tabular}

\section{Dose \& administration [3]}

5-10g Oral twice a day along with milk or water

\section{Actions [3]}

Muqawwi-e-Bah (Aphrodisiac), Mumsik (Semen Retentive)

\section{Therapeutic uses [3]}

Surat-e-Inzal (Premature ejaculation), Zof-e-Bah (Sexual debility) and Jiryan (Spermatorrhoea)

Table 3: Brief account of Ingredients of Majoon-e-Piyaz

\begin{tabular}{|c|c|c|c|c|}
\hline Ingredient & $\begin{array}{l}\text { Part } \\
\text { used }\end{array}$ & Botanical Name & Traditional use & Research Studies \\
\hline $\begin{array}{l}\text { Tudri surkh } \\
\& \\
\text { Tudri safaid }\end{array}$ & Seed & $\begin{array}{l}\text { Cheiranthus cheiri } \\
\text { L. } \\
\& \\
\text { Matthiola incana } \\
\text { R.Br. }\end{array}$ & $\begin{array}{l}\text { Premature ejaculation, } \\
\text { Spermatorrhoea \& } \\
\text { Nocturnal emission, } \\
\text { Sexual debility, } \\
\text { Erectile dysfunction, } \\
\text { Lactation insufficiency } \\
{[4,5]}\end{array}$ & $\begin{array}{l}\text { Seeds are aphrodisiac, stomachic and tonic. In } \\
\text { small doses it is a Cardiotonic but in more than } \\
\text { small doses it is toxic }[6,7] \text {. Zakai et al reported } \\
\text { the fertility potential of herbal formulation } \\
\text { containing seeds of C. cheiri. Test drug } \\
\text { formulation caused a significant improvement } \\
\text { in total sperm count and found effective in the } \\
\text { treatmemt of idiopathic oligospermia [8]. }\end{array}$ \\
\hline Salab Misri & Tuber & Orchis latifolia L. & $\begin{array}{l}\text { Oligospermia, Erectile } \\
\begin{array}{l}\text { dysfunction, Sexual } \\
\text { debility, Premature }\end{array} \\
\text { ejaculation, } \\
\text { Spermatorrhoea, } \\
\begin{array}{l}\text { Nocturnal emission, } \\
\text { Muscular weakness } \\
{[4,5]}\end{array}\end{array}$ & $\begin{array}{l}\text { Jagdale et al reported a significant increase in } \\
\text { (a) mounting behaviour, (b) reproductive organ } \\
\text { weights (c) sperm counts, (d) protein, (e) } \\
\text { haemoglobin and (f) testosterone content as } \\
\text { compared to control group in Swiss albino rats. } \\
\text { This proves the aphrodisiac potential of Orchis } \\
\text { latifolia. [9] }\end{array}$ \\
\hline Behman Surkh & Root & $\begin{array}{l}\text { Salvia haematodes } \\
\text { L. }\end{array}$ & $\begin{array}{l}\text { Sexual debility, } \\
\text { Oligospermia, } \\
\text { Spermatorrhoea, } \\
\text { Nocturnal emission, } \\
\text { Premature ejaculation, } \\
\text { Palpitation, Heart } \\
\text { disease debility, } \\
\text { General } \\
\text { depressed mood }[4,5]\end{array}$ & $\begin{array}{l}\text { Islam et al demonstrated the effect of ethanolic } \\
\text { extract ( } 500 \mathrm{mg} / \mathrm{kg} \text { bw), of } S \text {. haematodes roots } \\
\text { on sexual \& copulatory behaviour of male rats } \\
\text { thereby showing a significant increase in } \\
\text { episodes of penile erection and ejaculation } \\
\text { latency, and enhanced orientation of males rats } \\
\text { towards the female. [10] } \\
\text { Another study reported enhanced anabolic } \\
\text { activity, testicular function and sexual } \\
\text { behavioural performance in a dose-dependant } \\
\text { manner in male rats when treated with Salvia } \\
\text { haematodes roots extract. [11] }\end{array}$ \\
\hline Behman Safaid & Root & Centaurea behen L. & $\begin{array}{l}\text { Sexual debility, } \\
\text { Oligospermia, } \\
\text { Spermatorrhoea, } \\
\text { General debility }[4,5]\end{array}$ & $\begin{array}{l}\text { Ethanol extractive of C. behen showed } \\
\text { significant anxiolytic activity at a dose of } 200 \\
\mathrm{mg} / \mathrm{kg} \text { which was statistically significant to } \\
\text { standard drug diazepam [12] }\end{array}$ \\
\hline
\end{tabular}




\begin{tabular}{|c|c|c|c|c|}
\hline Zanjabeel & Rhizome & $\begin{array}{l}\text { Zingiber officinale } \\
\text { Rosc. }\end{array}$ & $\begin{array}{l}\text { Sexual debility \& } \\
\text { Impotancy; Nervine } \\
\text { disorders }[4,5]\end{array}$ & $\begin{array}{l}\text { It was demonstrated that extract of Zingiber } \\
\text { officinale possesses pro-fertility properties in } \\
\text { male broiler which might be a product of both } \\
\text { its potent antioxidant properties and } \\
\text { androgenic activities. [13]. Another study } \\
\text { revealed a significant androgenic activity of } \\
\text { Ginger on testicular histology of adult Sparague } \\
\text { Dawley rats [14]. } \\
\text { Study showed the protective effects of the } \\
\text { ginger extract by increasing antioxidant defence } \\
\text { and suppression free radicals production in the } \\
\text { serum of male rats. [15] } \\
\text { One more study reported significant } \\
\text { antidepressant activity of Ginger extract } \\
\text { comparable to the standard drug seems to be } \\
\text { mainly associated with the activation of } \\
\text { dopaminergic system. [16] }\end{array}$ \\
\hline $\begin{array}{l}\text { Tukhm-e-Piyaz } \\
\text { \& Aab-e-Piyaz } \\
\text { Safaid }\end{array}$ & $\begin{array}{l}\text { Seeds } \\
\& \\
\text { Extract } \\
\text { of Onion }\end{array}$ & Allium сера L. & $\begin{array}{l}\text { Sexual \& Nervine } \\
\text { debility, Oligospermia } \\
\text { Erectile dysfunction, } \\
\text { decreased libido }[4,5]\end{array}$ & $\begin{array}{l}\text { Banihani reported that onion or its extracts } \\
\text { (e.g., aqueous extract } \sim 30 \mathrm{mg}^{-1} \text { day enhances } \\
\text { testosterone production in males. The } \\
\text { mechanisms by which onion enhances } \\
\text { testosterone production in males is mainly by } \\
\text { enhancing the production of luteinizing } \\
\text { hormone, neutralizing the damaging effects of } \\
\text { the formed free radicals, mainly in the testes, } \\
\text { enhancing the antioxidant defense mechanism } \\
\text { in the testis, ameliorating insulin resistance, } \\
\text { promoting nitric oxide production in Leydig } \\
\text { cells, and altering the activity of } 5^{\prime} \text { AMP- } \\
\text { activated protein kinase [17]. }\end{array}$ \\
\hline Tukhm-e-Turb & Seed & $\begin{array}{l}\text { Raphanus sativus } \\
\text { L. }\end{array}$ & Sexual debility [4] & $\begin{array}{l}\text { Manhal et al revealed that extract of } R \text {. sativus } \\
\text { causes improvement in the reproductive } \\
\text { performance of male wistar rats. Body weights } \\
\text { were significantly decreased, while testicular } \\
\text { weight increased in a dose dependant manner } \\
\text { following administration of extract. It also } \\
\text { improved the semen characteristics and } \\
\text { significantly elevated the level of fertility } \\
\text { hormones i.e. testosterone, Follicle-stimulating } \\
\text { hormone (FSH), and Luteinizing hormone (LH) } \\
\text { [18] }\end{array}$ \\
\hline Talmakhana & Seed & $\begin{array}{l}\text { Hygrophila } \\
\text { auriculata } \\
\text { (Schum.) Heine. / } \\
\text { Asteracantha } \\
\text { longifolia } \\
\text { (L.) Nees }\end{array}$ & $\begin{array}{l}\text { Spermatorrhoea, } \\
\text { Nocturnal emission, } \\
\text { Watery semen, } \\
\text { Premature ejaculation } \\
\text { Sexual debility, } \\
\text { Oligospermia, } \\
\text { Gonorrhoea and } \\
\text { urethral dialation, } \\
\text { Depressive mood [4] }\end{array}$ & $\begin{array}{l}\text { Chauhan et al reported that ethanolic extract of } \\
\text { seeds of A. longifolia were administered to } \\
\text { groups of rats in } 100,150 \text { and } 200 \mathrm{mg} \mathrm{kg}^{-1} \\
\text { doses which exhibited pronounced anabolic } \\
\text { effects in treated animals, as evidenced by gains } \\
\text { in the body and reproductive organ weights. } \\
\text { Increased spermatogenesis was also witnessed } \\
\text { in transverse section. The treatment further } \\
\text { markedly affected sexual behaviour of the } \\
\text { animals, as reflected by the reduction of ML, } \\
\text { increase in MF and enhanced attractability } \\
\text { towards females. A significant increase in the } \\
\text { sperm count as well as fructose levels of } \\
\text { seminal vesicles was noted [19] }\end{array}$ \\
\hline Musli safaid & Root & $\begin{array}{l}\text { Chlorophytum } \\
\text { arundinaceum } \\
\text { Baker. }\end{array}$ & $\begin{array}{l}\text { Sexual debility, } \\
\text { Oligospermia, } \\
\text { Spermetorrhoea, } \\
\text { Impotency, General } \\
\text { debility }[4,5]\end{array}$ & $\begin{array}{l}\text { As demonstrated by Kenjale et al. rats were } \\
\text { orally treated with dried roots powder of } C \text {. } \\
\text { borivilianum } 125 \mathrm{mg} / \mathrm{kg} / \mathrm{day} \text { and } 250 \\
\mathrm{mg} / \mathrm{kg} / \mathrm{day} \text { and their sexual behavior was } \\
\text { monitored } 3 \text { hour later using a receptive } \\
\text { female. Their sexual behavior was evaluated on } \\
\text { days } 1,7,14,21 \text { and } 28 \text { of treatment by pairing } \\
\text { with a pro-oestrous female rat. For sperm count } \\
\text { the treatment was continued further for } 60 \\
\text { days. At } 125 \mathrm{mg} / \mathrm{kg} \text {, CB had a marked } \\
\text { aphrodisiac action, increased libido, sexual } \\
\text { vigor and sexual arousal. Similarly, at the higher } \\
\text { dose }(250 \mathrm{mg} / \mathrm{kg} \text { ) all the parameters of sexual } \\
\text { behaviour were enhanced, but showed a }\end{array}$ \\
\hline
\end{tabular}




\begin{tabular}{|c|c|c|c|c|}
\hline & & & & $\begin{array}{l}\text { saturation effect after day } 14 \text {. On day } 60 \text { the } \\
\text { sperm count increased significantly in both } 125 \\
\mathrm{mg} / \mathrm{kg} \text { and } 250 \mathrm{mg} / \mathrm{kg} \text { groups in a dose } \\
\text { dependent manner. Thus, it is evident that roots } \\
\text { of } C \text {. borivilianum can be useful in the treatment } \\
\text { of certain forms of sexual inadequacies, such as } \\
\text { premature ejaculation and oligospermia [20] }\end{array}$ \\
\hline Musli siyah & Root & $\begin{array}{l}\text { Curculigo } \\
\text { orchioides Gaertn. }\end{array}$ & $\begin{array}{l}\text { Oligospermia, } \\
\text { Spermetorrhoea,Impo } \\
\text { tency, General } \\
\text { debility }[4,5]\end{array}$ & $\begin{array}{l}\text { Studies revealed that ethanolic extract of } C \text {. } \\
\text { orchioides rhizome significantly changed the } \\
\text { sexual performance as assessed by determining } \\
\text { parameters such as penile erection, mating } \\
\text { performance, mount frequency and mount } \\
\text { latency [21]. It is also demonstrated that } C \text {. } \\
\text { orchioides had pronounced effect on orientation } \\
\text { of male towards the female rats. Further, } \\
\text { increased spermatogenesis in treated group } \\
\text { was confirmed by change in histoarchitecture } \\
\text { as evidenced by increase in number of } \\
\text { spermatocyte and spermatids [22]. }\end{array}$ \\
\hline
\end{tabular}

\section{Conclusion}

Majoon-e-Piyaz is a Unani pharmacopoeial formulation indicated in the treatment of Premature Ejaculation and in use since centuries. As evidenced by various research studies the polyherbal formulation is found in accordance with the claims made by Unani physicians. Hence, Majoone-Piyaz should be considered as first line of drug in the management of Premature Ejaculation.

\section{Conflicts of interest}

The authors declare no conflict of interest.

\section{References}

1. Anonymous. National Formulary of Unani Medicine. $1^{\text {st }}$ reprint, Government of India Ministry of Health \& Family Welfare (Department of AYUSH). Publisher: Central Council for Research in Unani Medicine, New Delhi. Part-I; (2006).139 p.

2. Anonymous. The Unani Pharmacopoeia of India. $1^{\text {st }}$ Edition, Government of India Ministry of AYUSH, New Delhi. To be published by Pharmacopoeia Commission of Indian Medicine \& Homeopathy, Ghaziabad. Part-II, Vol. IV (Formulations); (YNM).121-23 p.

3. Anonymous. Physicochemical standards of Unani formulations. Government of India Ministry of Health \& Family Welfare. Publisher: Central Council for Research in Unani Medicine, New Delhi. Part-2; (1987).138-40 p.

4. Ghani M.N. Khazain-ul-adviya. Publisher: Central Council for Research in Unani Medicine. Printed by New India Offset Printers, 1231, Churiwalan, Delhi. (2010).Vol. II (37, 457p); Vol. III(113; 148; 200; 231p.); Vol. VI (341; 351p).

5. Ali S.S. Unani Adviya Mufarrada. $5^{\text {th }}$ edition, Qaumi Council Barae Farogh-e-Urdu Zaban, Institutional Area, Jasola, New Delhi. (2010; 87:108, 117, 175, 244, 266.

6. Al-Snafi AE. Traditional uses of Iraqi medicinal plants IOSR Journal of Pharmacy 2018; 8(80:32-95.

7. Khare CP. Indian Medicinal Plants- An illustrated dictionary. Publisher; Springer Science + Business Media, LLC. New York, USA. (2007). 140-41p, 401p.

8. Zakai MF, Nazar H, Usmanghani K, Ayaz S. Study of fertility potential in Oligospermia with herbal dosage form design. Mintage J Pharm \& Med Sci; 2012: 1(1):14-16.

9. Jagdale SP, Shimpi S, Chachad D. Pharmacological studies of 'Salep'. Journal of Herbal Medicine and Toxicology; 2009: 3(1):153-156.
10. Islam MW, Tariq M, Ageel AM, Al-Said MS, Al-Yhya AM. Effect of Salvia haematodes on sexual behaviour of male rats. Journal of Ethnopharmacology. 1991; 33(1-2):67-72.

11. Bansode FW, Rajendran SM, Singh RK. Dose-dependent effects of ethanol extract of Salvia haematodes Wall roots on reproductive function and copulatory behaviour in male rats $\begin{array}{llll}\text { aNDROLOGIA } & 12 & \text { March }\end{array}$ https://doi.org/10.1111/and.12255

12. Singh B, Sharma A and Ishar MPS. Antianxiety Investigations of Centaurea behen Linn. and Elaeocarpus ganitrus Roxb. Journal of Pharmacy Research 2012, 5(3):1483-1486

13. Saeid JM, Shanoon AK, Marbut MM. Effects of Zingiber officinale. Aqueous Extract on Semen Characteristic and Some Blood Plasma, Semen Plasma Parameters in the Broilers Breeder Male. Int J Poult Sci. 2011; 10 (8):629-633.

14. Ghlissi Z, Atheymen R, Boujbiha MA, Sahnoun Z, Makni Ayedi F, Zeghal K, El Feki A, Hakim A. Antioxidant and androgenic effects of dietary ginger on reproductive function of male diabetic rats. Int J Food SciNutr. 2013; (64):974-978.

15. Al-Katib SM, Al-Khashab EM, Kalo MS, Hamdoon AA. The Antioxidant Effects of Flavonoids and non Flavonoid Part Extracted from Ginger (Zingiber officinale) Roots. Jou Raf Sci. 2009; (20):18-31.

16. Pratap SR, Ritesh J, Rahul M, Prashant T. Antidepressant activity of hydroalcoholic extract of Zingiber officinale. International Research Journal of Pharmacy. 2012; (3):149151.

17. Banihani SA. Testosterone in Males as Enhanced by Onion (Allium Cepa L.) Biomolecules. 2019 Feb; 9(2):75. Published online 2019 Feb 21. doi: 10.3390/biom9020075 PMCID: PMC6406961. PMID: 30795630

18. Manhal M. Dafaalla, Salah Abdoun , Abdel Wahab Hassan and Omer Fadl Idris. Effects of ethanolic extract of Raphanus sativus seeds on fertility hormone and sperm parameters in male wistar rats. World J. Pharm. Res. 2017; 6 (5):28-36. DOI: 10.20959/wjpr20175-8315

19. Chauhan NS, Sharma V, Dixit VK. Effect of Asteracantha longifolia seeds on the sexual behaviour of male rats. Nat Prod Res. 2011 Sep; 25(15):1423-31.

20. Sharma $P$, Chandrul $K K$. Chlorophytum borivilianum (Safed musli): A Vital Herbal Drug Int. J. Pharm. Med. Res. 2017; 5(1):401-411

21. Chauhan NS, Rao $\mathrm{ChV}$ and Dixit VK: Effect of Curculigo orchioides rhizomes on sexual behaviour of male rats. Fitoterapia 2007; 78(7-8):530-534.

22. Chauhan NS and Dixit VK: Spermatogenic activity of rhizomes of Curculigo orchioides Gaertn in male rats. International Journal of Applied Research in Natural Products 2008; JuneJuly, 1(2):26-31. 